\title{
Androgen Receptor Downregulator AZD3514
}

National Cancer Institute

\section{Source}

National Cancer Institute. Androgen Receptor Downregulator AZD3514. NCI Thesaurus. Code $C 116726$.

An orally available selective androgen receptor (AR) downregulator (SARD), with potential antineoplastic activity. Upon oral administration, AZD3514 binds to the AR ligand binding domain and inhibits the binding of androgen, thereby preventing androgen-dependent AR signaling. AZD3514 also causes downregulation of AR expression, which further prevents AR-mediated signaling. This results in an inhibition of proliferation in AR-overexpressing tumor cells. AR plays a key role in the proliferation of castration-resistant prostate cancer cells. 